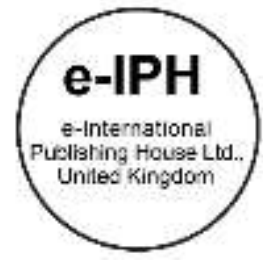

\title{
Exploring the Communicative Capability Challenges of Architectural Undergraduates
}

\author{
Nik Mastura Nik Mohammad¹, Siti Akmar Abu Samah², Ahmad Mazli Muhammad² \\ 1 Department of Landscape Architecture, Faculty of Architecture, Planning and Surveying, \\ Universiti Teknologi MARA 42300 Puncak Alam Selangor, Malaysia \\ 2Akademi Pengajian Bahasa, \\ Universiti Teknologi MARA 40450 Shah Alam Selangor, Malaysia \\ nikmasturanikmohammad@yahoo.com.sg, sitiakma@salam.uitm.edu.my, a.mazli@salam.uitm.edu.my \\ Tel:0192826229
}

\begin{abstract}
Concern on communicative capability of undergraduates in local universities has been a perennial issue. Language facilitators find it a challenge to accommodate this concern. They have also been continuously putting effort to sustain several language teaching and learning approaches. However, with every incoming cohorts of undergraduates, they bring along similar issues in language proficiency. Even in Malaysian media, it seems to expose the unfavourable stand with regard to undergraduates' deficiency in their communicative skills in terms of their future employability. Unemployment rate among graduates has also appeared to be strongly linked to this factor. However, continuous effort too has to be on the way to resolve this communicative challenge associated with poor English proficiency among them. This paper attempts to study these challenges by exploring the problems that undergraduates face with regards to their language incapability. The identification of these challenges is an important task in selecting appropriate undergraduates to be future architect registered (Ar). The aim of this study is to identify the most critical challenges faced by an Ar for undergraduates. Data is collected via a written interview conducted on selected group of architecture students to present their perceptions and experiences in acquiring proficiency. Their views in relation to the oral communication in their learning environment are highlighted as drawn from observations and interviews excerpts. The data seem to suggest that although they are technically sound in their field of studies, they aspire to possess the communicative skills in order to market themselves. These vital skills which are closely related to employability and workplace literacy need to be further enhanced in determining the graduates' success or failure in the workplace.
\end{abstract}

Keywords: undergraduates, communicative capability, employability, architecture

eISSN: 2398-4287 (C 2018. The Authors. Published for AMER ABRA cE-Bs by e-International Publishing House, Ltd., UK. This is an open access article under the CC BYNC-ND license (http://creativecommons.org/licenses/by-nc-nd/4.0/). Peer-review under responsibility of AMER (Association of Malaysian Environment-Behaviour Researchers), ABRA (Association of Behavioural Researchers on Asians) and cE-Bs (Centre for Environment-Behaviour Studies), Faculty of Architecture, Planning \& Surveying, Universiti Teknologi MARA, Malaysia.

DOI: https://doi.org/10.21834/e-bpj.v3i8.1405

\subsection{Introduction}

Concern on communicative capability of undergraduates in local universities has been a perennial issue (Normazidah et al, 2012). Language facilitators find it a challenge to accommodate this concern. They have also been continuously putting effort to sustain several language teaching and learning approaches. However, with every incoming cohorts of undergraduates, they bring along similar issues in language proficiency. Hence, this present study is an attempt to explore what the challenges are; that are being faced by undergraduates as far as English is concerned.

eISSN: 2398-4287@ 2018. The Authors. Published for AMER, ABRA \& cE-Bs by e-International Publishing House, Ltd., UK. This is an open access article under the CC BYNC-ND license (http://creativecommons.org/licenses/by-nc-nd/4.0/). Peer-review under responsibility of AMER (Association of Malaysian Environment-Behaviour Researchers), ABRA (Association of Behavioural Researchers on Asians) and cE-Bs (Centre for Environment-Behaviour Studies), Faculty of Architecture, Planning \& Surveying, Universiti Teknologi MARA, Malaysia.

DOI: https://doi.org/10.21834/e-bpj.v3i8.1405 
Report from the media has it that among the youths in the workforce, those unemployed seemed to be higher in percentage among those with tertiary education compared to the ones without tertiary education. Based on a study conducted in 2015, of the 405,000 youths with tertiary education, $15.3 \%$ were unemployed. Compare this to the unemployment among those without tertiary education, where out of the 2.162 million youths without tertiary education, only $9.8 \%$ were unemployed. Cited in a study by the Ministry of Education, a finding from an annual report stated that only $53 \%$ of the 273,373 graduates in 2015 were employed within six months of graduating. Another $18 \%$ opted to pursue their studies, while $24 \%$ were unemployed. These startling statistics are a cause for concern to further investigate the challenges of language learning.

From a study in collaboration between the Malaysian Ministry of Higher Education and Jobstreet, the main reasons why local graduates remain unemployed are due to lack of English proficiency and poor communication skills. Another study also found that one in four Malaysian fresh graduates remain unemployed for six months after their graduation, and that a majority of unemployed fresh graduates $(51 \%)$ are from local public universities. Hence, these statistical figures may seem to spot on lack of English proficiency as the setback in employing local graduates.

Such revealing statistics have called on the need to explore the challenges faced by undergraduates to be given the opportunity for employment. As it is a pioneer work, this paper intends to seek some insights from selected architecture students on the challenges that they face while learning English as a language proficiency course during their studies. In concurrence to a study by Kaur and Lee (2008), it was found that graduates' performance was often perceived to be lower than the employers' expectation with regards to all types of communication skills in English. The employers' emphasis was on oral communication skills, besides other skills such as presentation, listening, interviewing and conversational skills in English. They too lacked in soft skills such as the ability to communicate and did not have the appropriate aptitude level in English language (Yapp, 2008). Therefore, this paper explores the students' insights and experiences with regard to English language.

\subsection{Literature Review}

There have been several reasons for lack of English proficiency. In a general overview, this lack in the communicative skills have been identified in a study by Normazidah et al (2012). Some possible factors that result in low English literacy attainment among Malaysian learners indicated these reasons namely, English is viewed as a difficult subject to learn and it is used only to answer teacher's questions and spoken during English class. Furthermore, many of the other causes have been listed mainly as:

\# Learners tend to depend heavily on translation and dictionary use to find meanings

\# There is a lack of support to use English in the home environment and the community

\# Learners are found to have limited vocabulary as English reading materials are not always available

\# Learners display unwillingness and lack of motivation to learn English as they do not see the immediate need to use the language

\# Learners have inadequate or insufficient exposure to the language as there is a limited opportunity to use English outside the classrooms

\# English is not perceived as an important medium for communication as they use Bahasa Malaysia both for academic and personal interactions

Although these reasons may not be generalised to all learners, it does represent a majority of what language learners experience, not only in school, but also in institutions of higher education. The overall picture is discouraging and is indicative of the need to change the ways in which English language literacy is taught to Malaysian learners. In learning a second language or a foreign language, several researches have established that it is utmost important that learners receive maximum support in terms of supportive and conducive learning environment as well as adequate, meaningful language experience. Hence, this present study has undertaken some exploration based on responses from the undergraduates on what their English language learning experiences are.

Based on a study by Zaliza and Mohd Saparin (2014), it also concurs the increasing rate of unemployment among undergraduates have triggered great concern. The research investigated factors that have led to this perennial problem, namely graduates' attributes, lecturers' competency and quality of education. They found that majority of the respondents agreed that the graduates' attributes, lecturers' competency and the quality of education are among the factors that contribute to the unemployment problem among the Malaysian graduates nowadays. However, in this present study, the investigation scrutinised on the written responses of the selected respondents on their challenges in language learning. These responses lead to the discussions that follow in the next section.

Meanwhile, when demand on the graduates to have better teamwork and communication skills, it has to be at the grassroots that they are effectively trained or taught to arrive to the expectations of future employers. Their language capability may also need to be developed to meet global demand. With this exploration, the paper may provide insights on the expectation of the undergraduates in learning English at tertiary level. This course on English for professional communication provides advantage amongst recent graduates, hence the course has to continue to require a re-dress in order that they become compatible to the job-market. This paper presents the issues and challenges pertaining to the language learning in the context of becoming professionals.

\subsection{Method}

This study has its setting among the students of architecture faculty. Using a random sampling of ten students, these are students that have undergone a professional interaction course. The course comprises an intensive practical use of the language that prepares the students for workplace communication. The experience that they have to go through gives them a sensible amount of interaction which is deemed to be the expected situations. The students had to answer five questions using written answer based on the interview 
questions. These are individual interviews in which the expected answers are not imposing. They respondents were given ample space to decipher the interview questions and form answers that allowed them to express their views and form opinions on the students' communication competencies. The main aim is to understand the meaning or perspective from their points of view. The information gained from this method provided rich insights on issues and challenges pertaining to communication among these students of architecture, although there were only four returned questionnaires. The next section of this paper presents the analysis of the issues discussed based on the interviews.

\subsection{Findings and Discussion}

This section presents selected responses taken from the respondents in terms of the interview questions posed on them. There are four sets of respondents. Each has provided rich information as these responses were explored further to capture the insights of these language learners as far as English is concerned. As these are responses in actual form written by the respondents, there have been no attempt to conduct any editing or proofreading on the drafts. The exploration presents the questions posed and answers addressed.

\section{Question 1}

List 3 problems you face in English.

This is the first question posed for the written interview. Each section represents the responses by four selected respondents, in order of sequence namely Respondents $A, B, C$ and $D$. When asked about three problems they face in English, the respondents have the responses clearly stated as found in the table below.

\begin{tabular}{|c|c|}
\hline $\begin{array}{l}\text { Problem 1: } \\
\text { Problem2: } \\
\text { Problem 3: }\end{array}$ & $\begin{array}{l}\text { Lack of vocabulary. } \\
\text { Not confident to speak English. } \\
\text { Cannot speak fluently }\end{array}$ \\
\hline $\begin{array}{ll}\text { 1. } & \text { Not p } \\
\text { 2. } & \text { Lack } \\
\text { 3. } & \text { Pront }\end{array}$ & $\begin{array}{l}\text { per English and sometimes mix with Malay language } \\
\text { vocabulary } \\
\text { ciation difficulties in some word }\end{array}$ \\
\hline & $\begin{array}{l}\text { There is some word I forgotten in English } \\
\text { Lecturer using very high-level English language } \\
\text { Lecturer communicate with a fast paced }\end{array}$ \\
\hline $\begin{array}{l}\text { a. } \\
\text { b. } \\
\text { c. }\end{array}$ & $\begin{array}{l}\text { ually had conversation with broken English } \\
\text { metimes people did not understand what I am saying } \\
\text { ave difficult to pronounce some of words }\end{array}$ \\
\hline
\end{tabular}

From the responses presented three respondents clearly stated lack of vocabulary in the deficiency in English language problem. The respondents presented the issue on vocabulary that impede their communication. They also addressed the lack of confidence in using English. Back to basic of language learning, the foundation of proficiency has to be built upon vocabulary enhancement. This approach can be instilled via students being given the opportunity to acquire higher level of vocabulary during language lessons through independent learning (Siti Akmar et al, 2009).

\section{Question 2}

\section{On each problem explain in $\mathbf{5 0}$ words.}

The first question posed is further elaborated in the second question. The respondents need to elaborate on the problems they face using about 50 words. With the explanation, the researchers are able to decipher further the concerns faced by the language learners.

Problem 1: In this problem which is lack of vocabulary, I have this problem since I am not interested to read English book. I cannot understand clearly certain words that my friend or my lecturer use sometimes. The words is cliché and every one often use it and it sometimes be a trend.

Problem 2: $\quad$ Second problem is not confident to speak English. This is the worst problem that I have. I am so scared if I speak English and use the wrong term of English. I also feel ashamed if my friends laugh at me even if my grammar and words in English not good.

Problem 3: $\quad$ Third problem is cannot speak fluently. Sometimes, I have an idea in my mind on what the point that I want to speak. But I cannot speak it fluently. My grammar is too bad. Even though I am good in pronounce the words but I don't know how to make a sentence nice. I will be people that speak in broken English.

a) When I speak in English, sometimes I have to mix up with Malay words because I'm not able to translate certain words. Besides, in daily conversation also make me confuse to use the correct tenses. The bad grammatical errors that happen are sometime I use present tense, past tense and sometime I mix it up without knowing the correct timing.

b) Vocabulary also important to describe something which really portrays the real feelings. And the uses of good vocabulary also shows that a person really fluent in using English language. So, I'm using the same or normal word to express my feeling sometimes is not really works and sometimes people getting me wrong.

c) Some sophisticated word like narcissist that I cannot pronounce makes me sounds silly. So, instead of using it I find another word like highly self-centered to describe someone in a conversation. Sometimes l'm afraid to use sophisticated word because it will turn out weird when I wrongly pronounce it. 
Problem 1 : There are some word I forgotten I English, when talking in English, sometime I am having blank when I want to translate the Malay Language into English. I understand when people talking to me in English but when I want to say, my English become broken but the people I communicate to is still understand.

Problem 2: During a speaking class, some of lecturer tend to using high English language. I need to google the word to understand the meaning. Beside that using the slang in English sometime confusing me.

Problem 3: Some student cannot pickup with what the lecturer asked. Lecturer should uses loud and clear voice.

Problem 1: Conversation with broken English

The biggest problem is I had a very bad grammar. Sometimes I cannot differentiate either the words used for past tense and present tense. Other than that, I speak in Malays when I cannot figure out the exact words to describe something. Maybe I need to do a deep learn on grammar and improve my vocabulary.

\section{Problem 2: People cannot understand what I am saying}

When I try to speak in English sometimes people will give sorry-I-don't-understand face. As I try again to explain what I want to tell them it is getting more difficult and end up they will ask me to say it in Malays. This problem might also be occurring due to the words I use.

Problem 3: Trouble in pronounce some words

As possible as I can I will avoid saying the words that I cannot say it properly. This is because I just do not want people to misunderstand what I am try to tell them. Usually as best as I can I will try to replace the words with some other words that are having same meaning.

With this elaboration, it is clearly said about the learners' expectation on how English lessons have to be provided. Apart from their own limitations, the lecturers were said to have used the English language which the students claimed to be difficult to understand as stated "some of lecturer tend to using high English language. I need to google the word to understand the meaning. Beside that using the slang in English sometime confusing me." Hence, both learners and teachers have to come to terms to the level of English expected to be used in classroom interaction. Richards et al (2012) concur that although teachers may have extensive wide knowledge of their target teaching language, they may lack formal language teaching qualifications. Hence, it is necessary that training on English for effective teaching is promoted.

\section{Question 3}

\section{How do you want on English class to be?}

In my opinion, I want an interactive English class. I want my lecturer provide a lot of activities in class that include a teamwork and communication skills characteristics. Do a lot of presentation but not a presentation that burden students. It just fun and easy presentation that can interact students and make them so excited to share and present.

When I'm in secondary school my English teacher love to make fun activities like quiz. The quiz challenge us to know the correct words. It turns out very well when we listen to the song and fill up the blank lyrics. The learning is about the missing words actually. The words then explained by the teacher and she showed us how do we use the word in a sentence. This activity also makes a two way learning concept that actually very fun and enjoyable to the student. Other than that, a public speaking in the class also polish the speaking skills. Not only that, it also helps to increase confident level for the student

No more basic English, just teach what acquired by university student to improve his writing and speaking skill. Has some video learning cause this can attract us.

I prefer the concept of 2 ways interaction and fun learning concept. Maybe we can try something like we are doing during our school where there has a grouping activities in class, fun quizzes etc. Then have a quick revision on lesson of previous class like having an enjoyable quizzes or $Q$ and $A$ session.

This question addressed the proceed that came from Question 2, which respondents prefer to be taught. Although they are undergraduates, they would still prefer interactive lessons to be conducted, when Respondent B mentioned, "makes a two way learning concept that actually very fun and enjoyable to the student." As reiterated by Richards et al (2012), with the language teaching qualification, learning can be enhanced as far as language is concerned.

\section{Question 4}

\section{Are you happy with your level of English?}


Even though I got band 4 in my MUET examination, but I am not happy with my English level. I think I need to improve my English level. I need to learn on how to deal with my English vocabulary. I need to practice until I can speak fluently. I am so jealous with my friend that can speak English fluently. I believe I can improve my English level if I practice everyday.

I'm not very satisfied with my English because I'm not fluent enough in speaking English and even my writing also not so well. But at least I can start a conversation and communicate with foreigner and they understand what I'm telling them. But yet I have to improve my English since ii is very important nowadays.

Yes, I am happy with my English level. Because I can use it as long as people understand me.

Currently I think my English is in moderate level and yeah I am happy with this because at least I still can write, speak and understand properly if people talk in English with me. But, I think I still need to do something so that my English is much better than now.

Based on these responses, the students seem to have a satisfactory level of their English. This is presented by Respondent $\mathrm{C}$ as "I am happy with my English level" and Respondent D as "...think my English is in moderate level and yeah I am happy with this...". However, there are indications of hope to further improve their level of English. This is reiterated by Respondent A "I need to practice until I can speak fluently".

\section{Question 5}

\section{Do you want to work hard to improve your English? How?}

Yes, I want to improve my English. First, I need to speak English everyday. I should make English as my first language in my daily life. I need to find friends that also want to speak English everyday. Even though I speak broken English, but it can make me feels more confident and improve my English too. Besides, I need to make myself interested to read English book. I need to find any English book that can make me so excited to read. So that, it can make me feels like want to read English book everyday and improve my vocabulary. In a nutshell, I should watch English movies and listen to English songs. Once I watch the English movie, I need to follow what they said and learn how to make a nice sentence and use a proper grammar. So that, I can improve my English level.

Yes of course I want to improve my English. Since it is basic language in the industry nowadays, I need to very fluent in using this language. Currently I'm working on my vocabulary so I watch many English series with English subtitle, so that I can learn the words and find the meaning. Besides, sometimes I also read English news to know the current issues and the same time improve my vocabulary.

Yes, a guide to improve my writing. By providing by using I learn or something. You also can use a video.

Of course I need to work hard to improve my English as I know that nowadays English is really important. Currently I start reading book, novel and short story in English

I also watch English movie without Malay subtitle and if I really did not understand what they said I will turn on the subtitles but in English.

From this final question, there are elements of motivation projected by the respondents. They are hopeful for continuous improvement in their English. Some activities have already been conducted by them, such as reading materials in English, watching English movies and enhancing vocabulary by speaking English in various situations. This proves a positive attitude among undergraduates in English language learning. Therefore, continuous support from the institutions have to be provided.

\subsection{Conclusion}

Based on these responses, they have created a clear platform for the respondents to air the current challenges faced in English language learning experiences. Such challenges provide insights on what steps can be taken to help undergraduates to improve and enhance their communicative capability. This awareness on the significance of English usage in the workplaces would help to develop undergraduates the motivation to take learning of English more seriously. Being the dominant language used in both government and private companies, English remains personally, professionally and internationally recognized. Therefore, undergraduates have to start being motivated and regard English as a language to be used for their own good themselves in order to be successful for their future working experiences.

At the institution level, it is reasonable for the parties who are involved in the construction and the enhancement of the curriculum of the related to the field of study to conduct an in-depth study as well. This should be done in order to identify the problems that occur throughout the process of learning among the undergraduates. It is important to evaluate the suitability of the implementation of a curriculum in order to ensure it supports the production of qualified and competent human resources to meet the employment market. 


\section{References}

Ainol Madziah Zubairi \&Isarji Hj Sarudin.(2009). Motivation to learn a foreign language in Malaysia. GEMA: Online Journal of Language Studies, 9(2). pp 73-87. ISSN 1675-8021.

Hijh Siti Akmar Abu Samah, Hj Kamaruzaman Jusoff \& Abu Daud Silong (2009). Does Spoon-feeding Impede Independent Learning? Canadian Social Science, 5(3). pp 82-91.

Kaur, S. \& Lee, S.H. (2006). Analysing workplace oral communication needs in English among IT graduates. English for Specific Purposes. 5(1), p 8.

Mariana Yusoff \& Siti Akmar Abu Samah. (2013). Exploring the engineering communicative challenges amongst undergraduates. Mediterranean Journal of Social Sciences. 4(4), pp 59-64.

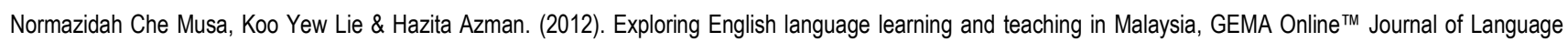
Studies 35. 12(1), Special Section, January 2012 ISSN: 1675-8021

Richards, H., Conway, C., Roskvist, A, \& Harvey, Sharon (2012). Foreign language teachers' language proficiency and their language teaching practice. pp 231-246. https://doi.org/10.1080/09571736.2012.707676

Yapp, E. (2008). Malaysia faces ICT gap. Sun2Surf. May 15. Retrieved 8.1.2009. http://www.zdnetasia.com/news/business/0.39044229.62041399.00htm

Zaliza Hanapi \& Mohd Safarin Nordin (2014). Unemployment among Malaysian graduates: graduates' attributes, lecturers' competency and quality of education. Procedia Social and Behavioural Sciences, 112(7) pp 1056-1063.

https://www.thestar.com.my/business/business-news/2017/03/25/unemployment-among-graduates-needs-to-sorted-out-fast/\#HcykDyMBL18ubxot.99 https://www.ihrnet.com/and-we-wonder-why-malaysian-graduates-remain-unemployed/ 


\section{Appendices}

These are written responses given by the respondents named as Respondents $A, B, C$ and $D$, who have submitted the questionnaire upon completion. These responses have become the basis for discussion in the paper. Nevertheless, these responses can be further rendered for deeper discussion in appropriate platforms.

\section{Respondent A}

1. List 3 problems you face in English.

A: $\quad$ Problem 1: Lack of vocabulary.

Problem2: $\quad$ Not confident to speak English.

Problem 3: $\quad$ Cannot speak fluently.

2. On each problem, explain in 50 words.

A: $\quad$ Problem 1: In this problem which is lack of vocabulary, I have this problem since I am not interested to read English book. I cannot understand clearly certain words that my friend or my lecturer use sometimes. The words is cliché and every one often use it and it sometimes be a trend.

Problem 2: $\quad$ Second problem is not confident to speak English. This is the worst problem that I have. I am so scared if I speak English and use the wrong term of English. I also feel ashamed if my friends laugh at me even if my grammar and words in English not good.

Problem 3: $\quad$ Third problem is cannot speak fluently. Sometimes, I have an idea in my mind on what the point that I want to speak. But I cannot speak it fluently. My grammar is too bad. Even though I am good in pronounce the words but I don't know how to make a sentence nice. I will be people that speak in broken English.

3. How do you want on English class to be.

A: $\quad$ In my opinion, I want an interactive English class. I want my lecturer provide a lot of activities in class that include a teamwork and communication skills characteristics. Do a lot of presentation but not a presentation that burden students. It just fun and easy presentation that can interact students and make them so excited to share and present.

4. Are you happy with your level of English?

A: Even though I got band 4 in my MUET examination, but I am not happy with my English level. I think I need to improve my English level. I need to learn on how to deal with my English vocabulary. I need to practice until I can speak fluently. I am so jealous with my friend that can speak English fluently. I believe I can improve my English level if I practice everyday.

5. Do you want to work hard to improve your English? How?

Yes, I want to improve my English. First, I need to speak English everyday. I should make English as my first language in my daily life. I need to find friends that also want to speak English everyday. Even though I speak broken English, but it can make me feels more confident and improve my English too. Besides, I need to make myself interested to read English book. I need to find any English book that can make me so excited to read. So that, it can make me feels like want to read English book everyday and improve my vocabulary. In a nutshell, I should watch English movies and listen to English songs. Once I watch the English movie, I need to follow what they said and learn how to make a nice sentence and use a proper grammar. So that, I can improve my English level.

\section{Respondent B}

1. 3 problem in speaking in English:

a) Not proper English and sometimes mix with Malay language

b) Lack of vocabulary

c) Pronunciation difficulties in some word

2. Explain in 50 words:

d) When I speak in English, sometimes I have to mix up with Malay words because I'm not able to translate certain words. Besides, in daily conversation also make me confuse to use the correct tenses. The bad grammatical errors that happen are sometime I use present tense, past tense and sometime I mix it up without knowing the correct timing.

e) Vocabulary also important to describe something which really portrays the real feelings. And the uses of good vocabulary also shows that a person really fluent in using English language. So, I'm using the same or normal word to express my feeling sometimes is not really works and sometimes people getting me wrong.

f) Some sophisticated word like narcissist that I cannot pronounce makes me sounds silly. So, instead of using it I find another word like highly self-centered to describe someone in a conversation. Sometimes l'm afraid to use sophisticated word because it will turn out weird when I wrongly pronounce it.

3. How do you want English class to be? 
When I'm in secondary school my English teacher love to make fun activities like quiz. The quiz challenge us to know the correct words. It turns out very well when we listen to the song and fill up the blank lyrics. The learning is about the missing words actually. The words then explained by the teacher and she showed us how do we use the word in a sentence. This activity also makes a two way learning concept that actually very fun and enjoyable to the student. Other than that, a public speaking in the class also polish the speaking skills. Not only that, it also helps to increase confident level for the student.

4. Are you happy with your level of English?

I'm not very satisfied with my English because l'm not fluent enough in speaking English and even my writing also not so well. But at least I can start a conversation and communicate with foreigner and they understand what I'm telling them. But yet I have to improve my English since ii is very important nowadays.

5. Do you want to work hard to improve your English? How?

Yes of course I want to improve my English. Since it is basic language in the industry nowadays, I need to very fluent in using this language. Currently l'm working on my vocabulary so I watch many English series with English subtitle, so that I can learn the words and find the meaning. Besides, sometimes I also read English news to know the current issues and at the same time improve my vocabulary.

\section{Respondent C}

1. List 3 problem you face in speaking class.

- $\quad$ There is some word I forgotten in English

- Lecturer using very high-level English language

2. Explain:

- Lecturer communicate with a fast paced

Problem 1 : There are some word I forgotten I English, when talking in English, sometime I am having blank when I want to translate the Malay Language into English. I understand when people talking to me in English but when I want to say, my English become broken but the people I communicate to is still understand.

Problem 2 : During a speaking class, some of lecturer tend to using high English language. I need to google the word to understand the meaning. Beside that using the slang in English sometime confusing me.

Problem 3: Some student cannot pickup with what the lecturer asked. Lecturer should uses loud and clear voice.

3. How do you want an English class to be?

No more basic English, just teach what acquired by university student to improve his writing and speaking skill. Has some video learning cause this can attract us.

4. Are you happy with your level of English?

Yes, I am happy with my English level. Because I can use it as long as people understand me.

5. Do you want to workhand to improve your English? How?

Yes, a guide to improve my writing. By providing by using I learn or something. You also can use a video.

\section{Respondent D}

1. List 3 problem you face in speaking English

d. Usually had conversation with broken English

e. Sometimes people did not understand what I am saying

f. Have difficult to pronounce some of words

2. On each problem explain in 50 words

Problem 1: Conversation with broken English

The biggest problem is I had a very bad grammar. Sometimes I cannot differentiate either the words used for past tense and present tense. Other than that, I speak in Malays when I cannot figure out the exact words to describe something. Maybe I need to do a deep learn on grammar and improve my vocabulary.

Problem 2: People cannot understand what I am saying

When I try to speak in English sometimes people will give sorry-I-don't-understand face. As I try again to explain what I want to tell them it is getting more difficult and end up they will ask me to say it in Malays. This problem might also be occurring due to the words I use.

Problem 3: Trouble in pronounce some words 
As possible as I can I will avoid saying the words that I cannot say it properly. This is because I just do not want people to misunderstand what I am try to tell them. Usually as best as I can I will try to replace the words with some other words that are having same meaning.

3. How do you want an English class to be? Describe in 50 words

I prefer the concept of 2 ways interaction and fun learning concept. Maybe we can try something like we are doing during our school where there has a grouping activities in class, fun quizzes etc. Then have a quick revision on lesson of previous class like having an enjoyable quizzes or $Q$ and $A$ session.

4. Are you happy with your level of English? Write in 50 words

Currently I think my English is in moderate level and yeah I am happy with this because at least I still can write, speak and understand properly if people talk in English with me. But, I think I still need to do something so that my English is much better than now.

5. Do you want to work hard to improve your English? How? (50 words)

Of course I need to work hard to improve my English as I know that nowadays English is really important. Currently I start reading book, novel and short story in English. I also watch English movie without Malay subtitle and if I really did not understand what they said I will turn on the subtitles but in English. 